\title{
Lembaran
}

Sejarah

\section{The Forgotten Medium: Hoso Kanri Kyoku and the Beginning of National Broadcasting in Indonesia}

\section{WIDYA FITRIA NINGSIH}

Vrij Universiteit

\begin{abstract}
This essay examines Hoso Kanri Kyoku, a bureau of radio centre and regulation, which has been much underestimated and understudied. It became an instrument of mass mobilization and mass psychology in the Japanese occupation period. The essay sees also the pivotal role of this institution in disseminating ideas of 'keIndonesiaan'. The aim of this essay is to show how the transformation process of the institution after the proclamation of Indonesian independence. The essay uses historical archival research as a method of data collection. This essay have indirectly presented that the Soeharto regime continued the legacy of the Japanese Military regime in Indonesia.
\end{abstract}

\begin{abstract}
Abstrak
Esai ini membahas tentang Hoso Kanri Kyoku, suatu badan pusat radio dan pengawas siaran radio, yang telah dipandang sebelah mata dan tidak banyak dikaji. Lembaga ini menjadi alat mobilisasi massa dan propaganda psikologi massa pada saat pemerintah Militer Jepang berkuasa di Indonesia. Esai ini juga melihat peran penting Hoso Kanri Kyoku dalam mensosialisasikan ide-ide 'ke-Indonesiaan. Tujuan dari esai ini adalah untuk menunjukkan bagaimana proses trasnformasi lembaga ini setelah proklamasi kemerdekaan Indonesia. Esai ini menggunakan penelitian arsip sebagai metode pengumpulan data. Esai ini secara tidak langsung menunjukkan bahwa rezim Suhato mewarisi kebijakan rezim Militer Jepang di Indonesia.
\end{abstract}

Keywords: radio; Hoso Kanri Kyoku; Japanese occupation period; Japanese legacy

\section{Kata Kunci:} radio; Hoso Kanri Kyoku; masa pemerintahan militer Jepang; warisan Jepang 


\section{Introduction}

\section{"Long live Queen Wilhelmina..!”}

The quotation is the last sentence from "Radio Bandung"1 before it was forced off the air by the Japanese, following the occupation of the Dutch East Indies in 8 March 1942 (Robbins, 2001: 93; Djamalul Abidin, 1985: 23). Japanese authorities then created Hoso Kanri Kyoku (a central office radio) as a tool of Japanese war propaganda. However, the story of Hoso Kanri Kyoku and its bequest are often neglected by historians and researchers. Many studies on broadcasting in Indonesia were focused on story of broadcasting in Dutch colonial period and after Indonesian independence. 2 There is a study about Japan's broadcasting which written by Jane Robins, Tokyo Calling. This study focuses on Japan's overseas radio propaganda in Second World War in broad terms. It analyses the whole course of war and compares it with developments in other countries, including Indonesia. Nevertheless, it does not elaborate on the inheritance of the Japanese broadcasting.

This essay will examine Hoso Kanri Kyoku and its legacy. The focus of the essay is elaborated into questions as follows: What kind of radio programs were presented by the Hoso Kanri Kyoku? Who were involved in the Hoso Kanri Kyoku? How did and to what extent did the Japanese use Hoso Kanri Kyoku as a tool of war and political propaganda? How did the Hoso Kanri Kyoku programs affect Indonesian society? Did the institution and its programs change or remain the same after political regime changing in Indonesia?

\section{'United in the Air': An outcome of Japan's Radio Policy}

According to Radio-telegrafie en kustverlichting in Nederlandsch-Indië, there were around 56 radio transmitters in the Dutch East Indies in 1931. Before arrival of Japanese troops, Dutch East Indies Government destroyed some of transmitters, particularly transmitters that were owned by private radio stations (radio particulier) that were incorporated into PPRK (Perserikatan Perkumpulan Radio Ketimuran), such as VORO (Vereniging Oostersche Radio Omroep) in Jakarta, VORL (Vereniging Oosterse Radio Luisteraas) in Bandung, MAVRO (Mataramsche Vereniging voor radio

1) In other publications, Radio Bandung was also called as Radio NIROM (NederlandIndische Radio Omroep Maatschappij) Bandung.

2) See Kementerian Penerangan Indonesia. Sedjarah Radio di Indonesia (Jakarta: Djawatan Radio Republik Indonesia (RRI), 1953), and Amrin Imran, Mestika Zed and Paini Mukhlis, Indonesia dalam Arus Sejarah 6:Perang dan Revolusi (Jakarta: Kementerian Pendidikan dan Kebudayaan, 2012), p.353. This is the newest textbook of Indonesian national history. In this book the history of the Japanese broadcasting and its bequestdescribes only in one paragraph. 
Omroep) in Yogyakarta, SRV (Solosche Radio Vereniging) in Solo, and CIVRO (Chinese Inheemse Radio Luisteraars Vereniging Oost Java) in Surabaya. Dutch East Indies Government was worried that transmitters would be used by Japan, whereas transmitters that were maintained by the Dutch East Indies Government radio, such as BRV (Bataviasche Radio Vereniging) in Jakarta and NIROM in Jakarta, Bandung, and Medan were sustained until they were seized by Japan in 1942.3 (Djamalul Abidin As, 1985: 21-25).

In March 1942, Japanese established Hoso Kanri Kyoku in Jakarta. It led by Tomabechi and had branches which were called Hoso Kyoku in several areas in Indonesia (Soebagijo, 1978: 40). In first six months of Japanese occupation, Hoso Kanri Kyoku broadcasted programs in Dutch, English, French and Arabic. Some Indonesians, such as Herawati Diah, Surjodipuro, Budiman, Ch. Tambu, Bachtiar Lubis, and B.M. Diah, were employed by this institution. They were given opportunity to create radio programs in the Indonesian language.

Due to lack of employee training, Japanese also recruited Dutchmen, such as Ritman and Zimerman, both of them were journalists in Dutch colonial period. They helped the Japanese to prepare English broadcast programs (Kementerian Penerangan Indonesia, 1953: 29). At the end of 1942, Japanese authorities changed their policy. They declared Indonesian and Japanese as official languages and banned use of foreign languages, especially Dutch. Consequently, all radio programs had to be delivered in Indonesian and/or Japanese4 (Djamalul Abidin As, 1985: 32), except English broadcast program that transmitted news about the Japanese victory during the war and daily life of the prisoners of war (POW's) in the Japanese camps.5

Different from the Dutch Government's radios that propagated the doctrine of ethical policy in their programs6 (Djamalul Abidin As, 1985: 22), Hoso Kanri Kyoku initiated several programs that evoked patriotism, nationalism and a strong sense of pride and self-confidence in being an Asian, such as traditional songs, wayang (traditional puppet), ketoprak (traditional

3) Bataviasche Radio Vereniging (BRV) was established in Weltevreden (Jakarta) in 16 Juni 1925, while NIROM was founded in 1934 and launched as Dutch East Indies Governments radio in 1 April 1934. PPRK was founded in 28 Maret 1937.

4) At the same time, Japanese permitted cultivation of Indonesian and established an Indonesian Language Commission in October 1942 to develop terminology and grammar.

5) Samenvattingen van de belangrijskte gegevens uit inlichtingen rapporten inzake Nederlands Indie Juli-September 1942, p. 5 (NA Inv. Nr.255). This archive quoted a report of POW's from radio in Batavia. I suppose that radio which mentioned in the archive was Hoso Kyoku in Jakarta.

6) The programs were intended to counterbalance the dissemination of national awareness after the declaration of Sumpah Pemuda in 28 October 1928. The Dutch Government also deliberately presented various entertainments such as Western songs and orchestra to divert Indonesian's attention from political issues. 
Javanese theatre), Malayan drama, radio comedy, and radio orchestra (Kementerian Penerangan Indonesia, 1953: 30). In radio orchestra program, Hoso Kanri Kyoku was not only broadcasting Japanese propaganda songs, for example Aikoku koshinkyouku (Patriotic March) and Aikoku no Hana (Flower of Patriotism), but also Indonesian patriotic songs, such as Rayuan Pulau Kelapa (The Coconut Island Persuasion), Bisikan Tanah Air (Whisper Motherland), Gagah Perwira (Gallant Officer), and Indonesia Tanah Pusaka (Indonesia, Land of Heritage) that composed by Ismail Marzuki. In 1944, these songs were suspected by section chief of Japanese imperial propaganda, Sumitsu. He reported Marzuki to the Kenpetai (Japan's (secret) military police). Consequently, Marzuki was threatened by the Kenpetai. However, in 1945 he composed another patriotic song, namely Selamat Jalan Pahlawan Muda (Goodbye, Young Hero). It was not clear how many songs that produced by Indonesian musicians during the Japanese occupation period (Asrul Sani, 1999: 90-91).

In addition, Hoso Kanri Kyoku spent considerable time on reporting speeches of prominent Indonesian leaders. Most frequently broadcasted on the radio was Soekarno. As a propaganda tool, Hoso Kanri Kyoku succeeded in creating an image of a strong and charismatic political leader, and impact on listeners was quite strong. One of Soekarno's speeches which was very influential talked about nationalism and collaboration with Japan to oppose Western imperialism (Radio Indonesia dan Masjarakat No.7, 1950: 1). Quoting Aiko Kurosawa (1987: 89), "The use of broadcasting for direct appeals by top politicians was the influence of Nazi Germany". In the days for Dutch colonialism, Indonesian leaders never had an opportunity to appeal directly to population.

Instead of gaining sympathy from Indonesians, existence of Hoso Kanri Kyoku to some extent united Indonesian society. As suggested by Anderson (2006: 137), "radio can conjure up imagined community to illiterates and different mother tongues". At that time, Indonesia did not exist yet but as a nation had been envisioned through Hoso Kanri Kyoku's programs, in particular speeches of Soekarno and radio orchestra that played Indonesian patriotic songs. But, unlike Soekarno's speech that propagandized 'collaboration with Japan', Indonesian patriotic songs, for example Indonesia Tanah Pusaka, urged to reject 'the Japanese assistance'. It can be seen from first stanza of the song that stated:

"Indonesia tanah air beta [...] Indonesia sejak dulu kala, selalu di pujapuja bangsa."(Suwito, 1985: 13).

Lyrics of the song can be interpreted that Indonesia already existed for a long time, her grandeur and greatness had been known by other nations, and Indonesia did not need assistance from foreigner like Japan. The song 
recalled the glorious past of Indonesia. It was often used by "kaum muda" as an allusion to Japan's occupation (Asrul Sani, 1999: 91).

Through Hoso Kanri Kyoku, Japanese not only instilled Nippon Seisyin or nationalism and anti-colonial spirit, but also Busido Seisyin or spirit of the Japanese warrior that compelled someone to adhere to Japan's authority. This effort was carried out with military training and radio calisthenics (Rajio Taiso). Rajio Taiso was conducted simultaneously every morning by students, civil servants, private workers and public in general prior to studying and working. The purpose of Rajio Taiso was conditioning the body while subjugating the individual will to authority. Many individuals synchronized into one collective movement by the rhythm of Rajio Taiso that broadcasted on the Hoso Kyoku in Jakarta. When people turned up at the appointed time to perform Rajio Taiso, those who failed to participate were viewed with suspicion, especially when one group vied to outdo another in demonstrating patriotic fervor through exercise.7 (Djamalul Abidin As, 1985: 33).

\section{What has Hoso Kanri Kyoku left for Indonesia?}

In the beginning of 1945, news of Japan's defeat was relayed by foreign radio stations, such as BBC London. The news was spread by Indonesian leaders so quickly and secretly. They used radio transmitter that had successfully been hidden from Japanese authority. Therefore, Japan became suspicious of Indonesian employees in Hoso Kanri Kyoku. All radio programs were censored by Japan. Finally, after proclamation of Indonesian independence, activity of Hoso Kanri kyoku was stopped in 19 August 1945. Due to former personnel of Hoso Kanri kyoku's insistence, Indonesian government formed Radio Republik Indonesia (here after RRI, Indonesian national radio station) in 11 September 1945. Before Japanese handed over all radio stations to the allied forces, R. Maladi as leader of RRI, and his staff succeed to convince Japanese to entrust all of them to Indonesian government. Since that time, Hoso Kanri Kyoku was reactivated under a new name, RRI. However, not all radio stations could be used by RRI, because some of them had been seized by the Dutch and Allied forces (Djamalul Abidin As, 1985: 35-38).

Until 1950s, there were 38 radio stations owned by RRI. Most of them were Japan's inheritance. Eight of them were located in Jakarta, and the others were located in Surakarta, Padang, Pontianak, Bandung, Jogjakarta, Surabaya, Semarang, Medan, Bukittinggi, Banjarmasin, Kediri, Madiun, Denpasar, Makassar, Palembang, Kotaradja, and Manado (Radio

7) Rajio Taiso was also imposed in Philippines by the Japanese. For further explanation in this topic see Ricardo T. José, 'Accord and Discord: Japanese Cultural Policy and Philippine National Identity during the Japanese Occupation (1942-1945)', in Li Narangoa and Robert Cribb (eds.), Imperial Japan and national identities in Asia, 1895-1945, (London: Routledge Curzon, Taylor \& Francis Group, 2011), pp. 261, 263. 
Indonesia dan Masjarakat No.7, 1950: 5). One of essential radio stations in revolutionary period was RRI Jogjakarta. It had special program, namely radio news in Javanese, Sundanese, Malayan, Minang, Padang, Maluku, Makassarese (South Sulawesi), etc. The news often reported Indonesian Republic political situation in Jogjakarta (Berita Radio, Radio Republik Indonesia Jogjakarta, 1-16 November 1947: 3). The use of vernacular language in news was probably intended to prevent information from falling into the Dutch and allied forces.

RRI also relayed speeches from Indonesian leaders, especially Bung Tomo, and speeches from political and social organization leaders, such as the leader of Partai Komunis Indonesia (PKI) and Kongres Wanita Indonesia (Kowani). The aim of these programs was to spread the Indonesian revolution spirit (Berita Radio, Radio Republik Indonesia Jogjakarta, 16-31 Oktober 1947: 1-3).

Moreover, RRI Yogyakarta was regularly broadcasting traditional songs, Indonesian songs, ketoprak, and wayang. Besides of traditional and Indonesian songs, Japanese patriotic song, such as Aikoku koshinkyouku was also played by RRI Yogyakarta (Berita Radio, Radio Republik Indonesia Jogjakarta, 16-31 Oktober 1947: 1-5). Some Indonesian old people can still sing this song. However, they seemed just to memorize the song without really understanding the meaning. 8 There was one song that was translated into Indonesian, namely Aikoku no Hana. Soekarno adored this song and under his regime it was taught in schools (Kuosawa, 1987: 86).

Similar with the Hoso Kanri Kyoku, RRI in Soekarno period has functioned as 'Government's mouthpiece' and cultural institution. Most of the government policies were publicized by RRI. RRI was also sponsored many Indonesian musicians in creating Indonesian songs (Radio Indonesia dan Masjarakat No.7, 1950: 2-4). Nevertheless, there was no more radio calisthenics. It can be traced from RRI's program schedule that published in the RRI magazine, Berita Radio and Radio Indonesia dan Masyarakat.9 This physical exercise became popular again under the Suharto regime.10 No wonder some Indonesians associated his regime with the Japanese.

\section{Conclusion}

Hoso Kanri Kyokubecame a tool of mass mobilization, mass institution and mass psychology in the Japanese occupation period. However, it was also playing a vital role in disseminating ideas of 'ke-Indonesian' and uniting

8) See Ina Isa Moru who asked to sing Aikoku koshinkyouku. https://www.youtube.com/ watch?v=-kAGywepuMc (Accessed, 2 April 2015).

9) See two exemplars of RRI magazine, Berita Radio, No.11 \& 12 (1947) and Radio Indonesia dan Masjarakat, No.7 (1950) that kept by special collection, library of Leiden University.

10) I myself did it every Friday morning when I was in elementary school. 
Indonesian population. After a change of political regime in Indonesia, Itwas transformed into RRI. It functioned as the official 'freedom radio' of the republic in the first year of its existence. Indonesian republic government adopted the Japanese policy in using radio, as witness several Hoso Kanri Kyoku programs were continued by RRI. However, the story of Hoso Kanri Kyoku and its legacy has been much underestimated and understudied.

\section{References}

Radio-telegrafie en kustverlichting in Nederlandsch-Indië. Amsterdam: Koloniaal Instituut, 1931.

Samenvattingen van de belangrijskte gegevens uit inlichtingen rapporten inzake Nederlands Indie Juli-September 1942 (NA Inv. Nr. 255).

Berita Radio, Radio Republik Indonesia Jogjakarta, No. 12, 1-16 November 1947, p. 1-6.

Berita Radio, Radio Republik Indonesia Jogjakarta. No. 11, 16-31 Oktober 1947, p. 1-7.

Radio Indonesia dan Masjarakat: Madjalah Bulanan untuk Menghubungkan Dunia Radio dengan Masjarakat Indonesia, No.7. Djakarta: Djawatan Radio, Bagian Hubungan Masyarakat, 1950.

Amrin Imran, Mestika Zed, Mukhlis Paini, Indonesia dalam Arus Sejarah 6: Perang dan Revolusi. Jakarta: Kementerian Pendidikan dan Kebudayaan, 2012.

Anderson, Benedict, Imagined Communities: Reflections on the Origin and Spread of Nationalism. London: Verso, 2006.

Asrul Sani,'Peristiwa-Peristiwa Kesenian yang Terjadi Selama Kurun Waktu 50 Tahun', Jurnal Sejarah, Pemikiran, Rekonstruksi, Persepsi, No.7, 1999, pp. 90-91.

D.S. Suwito M, Lagu-lagu Pilihan Ismail Marzuki. Jakarta: Titik Terang, 1985.

Djamalul Abidin As (ed.), 40 Tahun Radio Republik Indonesia: Sekali di Udara Tetap di Udara. Jakarta: Panitia Peringatan Hari Radio ke-40, 1985.

I.N. Soebagijo, Lima Windu Antara: Sejarah dan Perjuangannya. Jakarta: Lembaga Kantor Berita Nasional ANTARA, 1978.

José, Ricardo T. 'Accord and Discord: Japanese Cultural Policy and Philippine National Identity during the Japanese Occupation (1942-1945)', Li Narangoa dan Robert Cribb (eds.), Imperial Japan and national identities in Asia, 1895-1945. London: Routledge Curzon, Taylor \& Francis Group 2011, pp. 249-269.

Kementerian Penerangan Indonesia. Sedjarah Radio di Indonesia. Jakarta: Djawatan Radio Republik Indonesia (RRI), 1953. 
Kurosawa, Aiko, 'Propaganda Media on Java under the Japanese 1942-1945', Indonesia, No. 44, Oct. 1987, pp. 59-116.

Robbins, Jane, Tokyo Calling: Japanese Overseas Radio Broadcasting 19371945. Firenze, Italy: European Press Academic Publishing, 2001.

\section{Internet}

https://www.youtube.com/watch?v=-kAGywepuMc, accessed, 2 April 2015. 